\title{
Developmental changes in LH secretion by male pituitaries in vitro: from the infantile to adult period
}

\author{
J Bello-Pineda, J Luna, M C Romano and M E Mendoza \\ Department of Physiology, Biophysics and Neuroscience, CINVESTAV-IPN, México City, México \\ (Requests for offprints should be addressed to M E Mendoza Garrido, Depto. de Fisiología, Biofísica y Neurociencias, CINVESTAV-IPN, Av. IPN No. 2508 Col. \\ San Pedro Zacatenco, CP 07360, México)
}

\begin{abstract}
The secretion of LH from the anterior pituitary of male rats was studied at different periods of postnatal development. According to an established classification we used rats 14 (infantile), 23 (juvenile), 45 (pubertal) and 90 (adult) days old. By using an in vitro incubation system, both basal and stimulated LH secretion were studied in the same gland. Age-related differences were observed in basal LH secretion, with juvenile and pubertal pituitaries showing higher secretion compared with infantile and adult pituitaries. However, the GnRH-induced secretory response was significantly higher in the infantile rats than in other ages. LH secretion was also studied in primary cultures from infantile or adult pituitaries. In 24 and $48 \mathrm{~h}$ cultures, infantile cells showed a significantly larger response to GnRH than that of adult cells. In the infantile pituitary LH-immunopositive cells showed differences in
\end{abstract}

size at different locations in the gland. At the periphery of the lobes the predominant cells were smaller and angular shaped, whereas in the center of the gland the majority of the cells were ovoid shaped. In the adult pituitary, the predominant LH-positive cells were ovoid in shape and larger in size. Furthermore, 10\% more LH-positive cells were observed in infantile pituitaries. On the basis of these data we propose that at the infantile period the male rat pituitary has two populations of LH-secreting cells, one with adult secretory function and shape and a second with increased sensitivity to GnRH and with a morphology atypical of the adult cell. The results presented support the hypothesis that the infantile period is a transitional stage in the rat pituitary development.

Journal of Endocrinology (1999) 160, 333-341

\section{Introduction}

It is well documented that the hypothalamus-pituitarygonad axis is already established in the new-born male rat (Goldman et al. 1971, Swerdloff et al. 1971, Grady 1986, Negro-Vilar \& Valenca 1988, Lalau et al. 1990). However, and from a developmental point of view, the rat is born with a reproductive system comparable to that observed in humans at 150 days of gestation life (Ojeda \& Urbanski 1988).

In the male rat the serum concentration of luteinizing hormone (LH) fluctuates during postnatal development until adulthood is reached. Two peaks in LH serum concentrations have been observed: the first one starts in the second week, reaches its maximum at approximately 14 days of age and is followed by a rapid decline, whereas the second peak is present during the peripubertal period, between days 40 and 45 (Ojeda \& Ramírez 1972, Döhler \& Wuttke 1975, Chiappa \& Fink 1977). In contrast to these observations, the hypothalamic content of gonadotropin-releasing hormone $(\mathrm{GnRH})$ increases steeply between days 5 and 9 , with a less marked increase rate in hypothalamic GnRH content afterwards, until the adult stage is reached (Chiappa \& Fink 1977). On the other hand, Ojeda et al. (1977) found that the infantile female rat is more sensitive to GnRH compared with the neonatal and juvenile rat.

Dalkin et al. (1981) observed a sharp peak in GnRH receptor density in the pituitaries of female infantile rats. However, during this development stage male pituitaries showed only a discrete increase in GnRH-binding capacity, and the largest receptor density was observed in 30-day-old rats (Dalkin et al. 1981). Also, it has been shown that infantile male pituitary gonadotrope cells are heterogeneous, with a significant population of small cells (Denef et al. 1978, Childs et al. 1981) as in the female pituitary (Denef et al. 1978), and also they exhibit an irregular shape and a high nucleo-cytoplasmic ratio (Childs et al. 1981). Naor \& Childs (1981) observed that the smaller cells do not contain a measurable number of GnRH-binding sites and do not exhibit a GnRH-induced LH release. However, Denef \& Andries (1983) showed an LH-stimulated secretion ten times higher in gonadotrope cells from 14-day-old male rats compared with those obtained from adult males, but still to a lesser extent than 14-day-old female rats. From these observations it can be 
seen that male infantile LH gonadotrope cells share some morphological characteristics with infantile female cells. Although the higher LH secretion capacity by infantile female pituitaries is commonly accepted, the literature is still controversial about the functional pattern of LH secretion from male rat pituitaries at this development stage. The purpose of the present study was to compare the basal and GnRH-induced secretion of LH in pituitaries isolated from male rats at different stages of postnatal development, with emphasis on the infantile period.

\section{Materials and Methods}

\section{Animals}

Wistar male rats of different postnatal ages were used. The animals were bred in our colony and were maintained with free access to food and tap water. According to the classification proposed by Ojeda et al. (1980) we used rats 14 (infantile), 23 (juvenile), 45 (pubertal) and 90 (adult) days old. Fourteen-day-old animals were maintained with their mothers until used.

\section{Hormone secretion experiments}

The pituitary glands were removed and the anterior lobes were separated from the neurointermediate lobe and cut in half using a razor blade. The hemipituitary anterior glands of 23-, 45- and 90-day-old rats or the whole glands from 14-day-old rats were incubated for two 30 min periods for equilibrium. The incubation medium (medium 199 (Gibco, New York, NY, USA) plus 10 mM Hepes (Sigma Chemical Co., St Louis, MO, USA) and $4.7 \mathrm{mM}$ sodium bicarbonate, $\mathrm{pH} 7 \cdot 4$, at $37^{\circ} \mathrm{C}$ ) was placed in a syringe ( $3 \mathrm{ml}$ size and closed at the bottom, placed in a water bath) and gassed with $95 \% \mathrm{O}_{2} / 5 \% \mathrm{CO}_{2}$ through a thin needle (30 C 2 J, Becton Dickinson, Mexico City, Mexico). After these two periods the medium was discarded and replaced by fresh, and thereafter the glands were incubated for four consecutive periods of $20 \mathrm{~min}$ each, changing the medium in each period. The incubation volumes were $1 \mathrm{ml} /$ pituitary for 23-, 45- and 60-day-old rats, and $0.75 \mathrm{ml} /$ pituitary for 14-day-old rats. To examine the effect of $\mathrm{GnRH}$ on hormone release, the tissue was incubated for an initial basal period without GnRH, followed by three consecutive $20 \mathrm{~min}$ periods in the presence of the stimulus. Three different concentrations $(0 \cdot 01,1$ and $100 \mathrm{nM})$ of GnRH (Relefact, Hoechst, Frankfurt, Germany) were tested. The medium was collected at the end of each 20 min incubation period and replaced with new medium containing the same GnRH dose. Finally, the incubation media were centrifuged at $3200 \mathrm{~g} / 15 \mathrm{~min}$ and the supernatants were stored at $-20{ }^{\circ} \mathrm{C}$ until required for determination of LH by RIA. At the end of the experiment the glands were homogenized with $0 \cdot 05 \% \mathrm{NaOH}$ for protein content determination using the method of Bradford (1976). To test the diffusion capacity through the pituitary tissue of 14- and 90-day-old rats, the uptake of inulin was determined. The experiments were carried out using the same system described for the hormone secretion experiments, and the specific uptake of $\left[{ }^{3} \mathrm{H}\right]$ inulin $(1 \mu \mathrm{Ci} / \mathrm{ml}$; specific activity $2.6 \mathrm{Ci} / \mathrm{mmol}$, Amersham International, Amersham, Bucks, UK) was measured according to the method of Hernández et al. (1993). The $\beta$ emission was measured in a scintillation counter (Beckman, Palo Alto, CA, USA). Corrections for background and quenching were made. The $\left[{ }^{3} \mathrm{H}\right]$ inulin uptake by the $14-$ and 90-day-old rat pituitaries shows that the 14-day-old pituitary achieved a plateau in the uptake of inulin between $7 \cdot 5$ and $10 \mathrm{~min}$ of incubation and the 90-day-old hemipituitary reached a plateau after $12.5 \mathrm{~min}$ of incubation. The results indicate a small delay $(2 \cdot 5-5 \mathrm{~min})$ in adult hemipituitary $\left[{ }^{3} \mathrm{H}\right]$ inulin uptake when compared with the infantile gland. Also observed was a higher total uptake of inulin by the infantile pituitary tissue than by the adult tissue, which exhibits a larger interstitial space.

\section{Cell culture}

Anterior pituitaries from 14- and 90-day-old rats were used. Primary cultures of dissociated cells were prepared with minor modifications of a previously described procedure (Mendoza et al. 1995). Briefly, the glands were dissected, minced and treated with $0 \cdot 25 \%$ trypsin (1:250; Gibco) in $\mathrm{a} \mathrm{Ca}^{2+}$ - and $\mathrm{Mg}^{2+}$-free balanced salt solution for $10 \mathrm{~min}$. The cell dissociation was accomplished by passing the tissue fragments through a Pasteur pipette. Viability was always better than $95 \%$. Aliquots of $10^{5}$ cells/well were seeded in multiwell-plates (four wells, $11.3 \mathrm{~mm}$ well diameter; Nunc, Roskilde, Denmark) containing $1 \mathrm{ml}$ culture medium composed of medium 199 (Gibco), $10 \mathrm{mM}$ Hepes (Sigma) and $4.7 \mathrm{mM}$ sodium bicarbonate, supplemented with 10\% (v/v) fetal calf serum (Boehringer Mannheim GmbH, Mannheim, Germany) and 1\% antibiotics (penicillin $10000 \mathrm{U} / \mathrm{ml}$, streptomycin $10000 \mu \mathrm{g}$ / $\mathrm{ml}$; Gibco). Cell cultures were maintained in standard conditions and after 24 or $48 \mathrm{~h}$ were washed and incubated with $1 \mathrm{ml}$ serum-free medium for $60 \mathrm{~min}$. At the end of this period the medium was collected and replaced with fresh medium containing $100 \mathrm{nM} \mathrm{GnRH}$ and the cells incubated for another $60 \mathrm{~min}$. At the end of this period the medium was collected and stored at $-20{ }^{\circ} \mathrm{C}$ until assayed for LH.

\section{Immunocytochemistry for $\mathrm{LH}$}

Pituitaries of 14- and 90-day-old rats were removed and fixed for $60 \mathrm{~min}$ in $4 \%$ paraformaldehyde (Sigma) in Dulbecco's phosphate-buffered saline (DPBS, Gibco) at room temperature. After this period the glands were placed in 10\% sucrose (Merck, Darmstadt, Germany) in 
PBS and maintained at $4{ }^{\circ} \mathrm{C}$. Sagittal sections of $8-15 \mu \mathrm{m}$ were cut with a cryo-microtome (IEC minotome, Needham HTS, MA, USA) and placed in $0 \cdot 2 \%$ Triton $\mathrm{X}-100$ in tris-buffered saline for $15 \mathrm{~min}$. The sections were incubated at $4{ }^{\circ} \mathrm{C}$ overnight with guinea-pig primary antiserum against rat $\beta$-LH (1:5000), kindly provided by Dr Parlow through the National Hormone and Pituitary Program of the NIDDK (National Institute of Diabetes, Digestive and Kidney Diseases, Bethesda, MD, USA). Thereafter, the tissues were stained by the technique of alkaline phosphatase (ABC kit, Vector Labs, Burlingame, CA, USA) with Fast Red chromogen (BioGenex, San Ramón, CA, USA) and counterstained with Gill's hematoxylin. Posterior pituitary tissue was the negative control. The single labeled sections were viewed on a confocal laser scanning microscope (Bio-Rad MRC-600, Richmond, CA, USA) using a $2 \times, 4 \times$ and $60 \times$ oil immersion objective lens on an epifluorescence Nikon microscope (Nikon, Yokohama, Japan). For each observation, six to ten consecutive scanning fields were projected onto the two dimensional plane. The images were stored on 1000 rewritable optical disk cartridges and photographed on T-Max 100 film.

\section{$R I A$}

The LH concentration in the media was determined by double-antibody RIA employing the protocol and reagents generously supplied by the National Hormone and Pituitary Program (NIDDK, and the University of Maryland School of Medicine). The standard was NIDDK rat LH-RP2 with intra- and inter-assay coefficients of variation of $5 \cdot 5$ and $6.9 \%$ respectively.

\section{Data analysis}

All values are expressed as mean \pm s.E.M. Statistical analyses of the anterior pituitary incubation experiments were carried out using the Wilcoxon test for differences between incubation periods and by ANOVA followed by Student-Newman-Keuls multiple comparisons test for differences between age groups. Student's $t$-test was carried out for differences between LH secretion by 14and 90-day-old pituitary cells in culture. Statistical analysis of LH-positive cell diameters was performed using Kruskal-Wallis nonparametric ANOVA followed by Dunn's multiple comparison test (GraphPadInStat 1.14 1990, San Diego, CA, USA).

\section{Results}

\section{LH secretion from anterior pituitaries glands}

Figure 1 shows basal and stimulated LH secretion by anterior pituitaries from adult (90-day-old) rats. With $10^{-7} \mathrm{M} \mathrm{GnRH}$, the highest concentration tested, a clear
ADULT

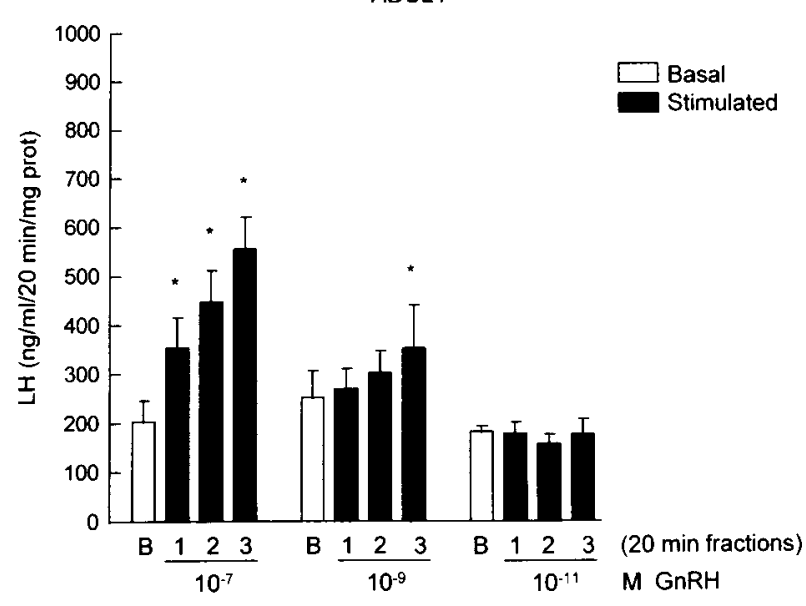

Figure $1 \mathrm{LH}$ secretion of hemipituitaries from 90-day-old male rats stimulated with different GnRH concentrations. Values are means \pm S.E.M., $n=6$. Comparisons with respect to basal secretion of each gland; ${ }^{*} P<0 \cdot 05$, Wilcoxon nonparametric test.

response is observed during the first incubation period, with further increases in $\mathrm{LH}$ secretion during the second and third periods of incubation. A GnRH concentration of $10^{-9} \mathrm{M}$ induced an increase in $\mathrm{LH}$ secretion, but the effect was observed only in the third period $(P<0 \cdot 05)$. No response was observed with the lower GnRH concentration used $\left(10^{-11} \mathrm{M}\right)$. Figure 2 presents the results of LH secretion obtained from the anterior pituitaries of 45-day-old rats (pubertal rats). These glands responded to $10^{-7} \mathrm{M} \mathrm{GnRH}$, which is very similar to that of the adult glands. However, with $10^{-9} \mathrm{M}$ GnRH a significant increase in LH secretion was observed after the first incubation period. Again, $10^{-11} \mathrm{M}$ GnRH did not elicit

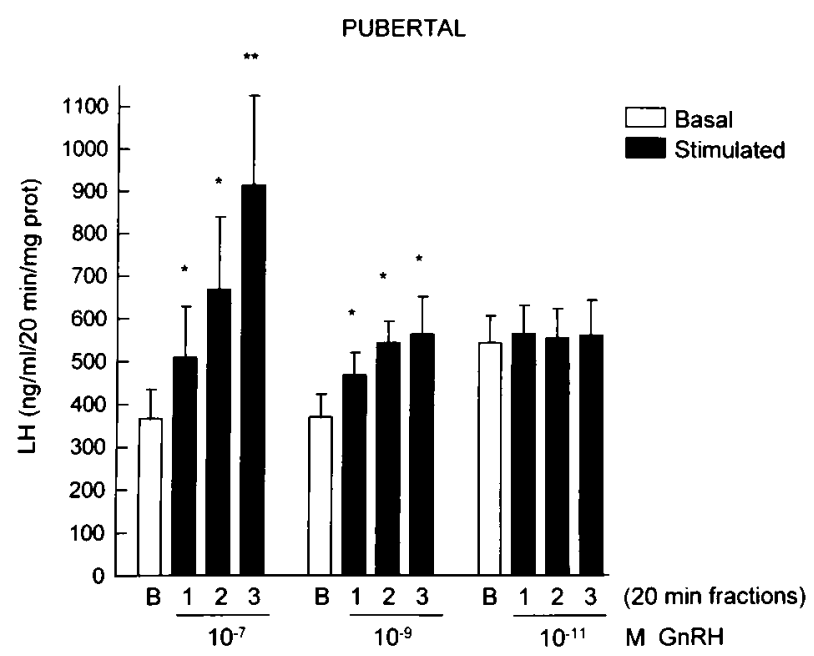

Figure 2 LH secretion of hemipituitaries from 45-day-old male rats stimulated with different GnRH concentrations. Values are means \pm S.E.M., $n=10$. Comparisons with respect to basal secretion of each gland; ${ }^{* *} P<0 \cdot 01,{ }^{*} P<0 \cdot 05$, Wilcoxon nonparametric test. 


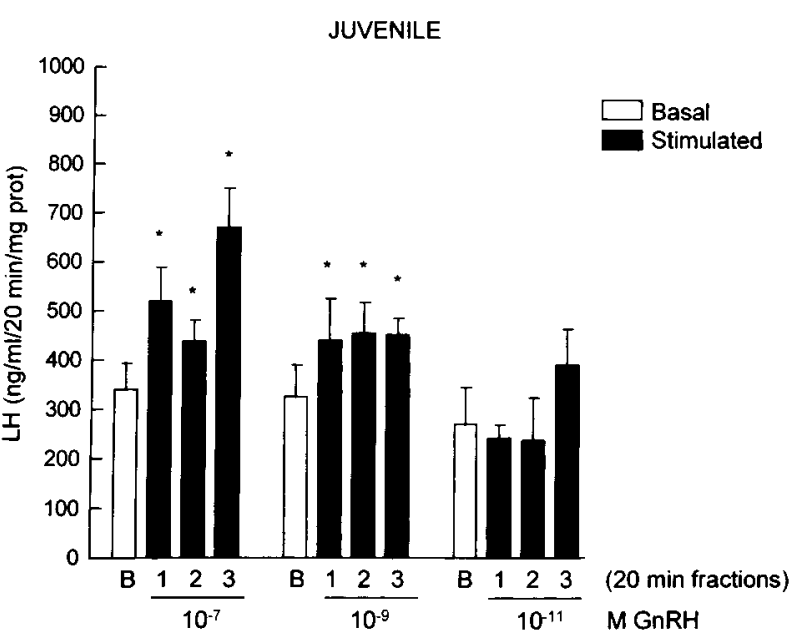

Figure $3 \mathrm{LH}$ secretion of hemipituitaries from 23-day-old male rats stimulated with different GnRH concentrations. Values are means \pm S.E.M., $n=10$. Comparisons with respect to basal secretion of each gland; ${ }^{*} P<0 \cdot 05$, Wilcoxon nonparametric test.

any significant stimulation. The LH secretion from 23-day-old rats (juvenile) is illustrated in Fig. 3. As shown for the pituitaries from pubertal rats, an increase in $\mathrm{LH}$ secretion was obtained with both $10^{-7}$ and $10^{-9} \mathrm{M}$ $\mathrm{GnRH}$, and the increment in LH secretion was statistically significant after the first 20 min stimulation period. When comparing the total amount of GnRH-induced $\mathrm{LH}$ release above basal secretion, the stimulated LH secretion was slightly less in juvenile pituitaries than in the pubertal glands (Fig. 4). In contrast, the stimulated LH secretion obtained with pituitaries from 14-day-old rats (infantile) is significantly higher than the secretion from pituitaries of 90- and 23-day-old rats and similar to that of 45-day-old rat pituitaries (Fig. 5). The higher response to GnRH was observed during the first period of stimulation. Figure 4 is a summary of the increase in $\mathrm{LH}$ secretion during the three stimulation periods with the three $\mathrm{GnRH}$ concentrations tested on the anterior pituitaries from infantile, juvenile, pubertal and adult male rats. The highest stimulated LH secretion was obtained with infantile pituitaries in the presence of $10^{-7} \mathrm{M} \mathrm{GnRH}$. Furthermore, infantile glands stimulated with $10^{-9} \mathrm{M}$ GnRH released LH in concentrations similar to those obtained with juvenile, pubertal and adult pituitaries in response to a 100-times higher dose of $\mathrm{GnRH}$. Another remarkable difference in LH secretion between infantile and both pubertal and juvenile anterior pituitaries was the rate of basal secretion (Table 1). Basal LH secretion observed for infantile anterior pituitaries was $67 \cdot 3$ and $61 \cdot 3 \%$ less than those obtained from pubertal and juvenile glands respectively.

\section{Anterior pituitary cell culture}

The GnRH-stimulated secretion of $\mathrm{LH}$ from cultured anterior pituitary cells from 14- and 90-day-old rats also

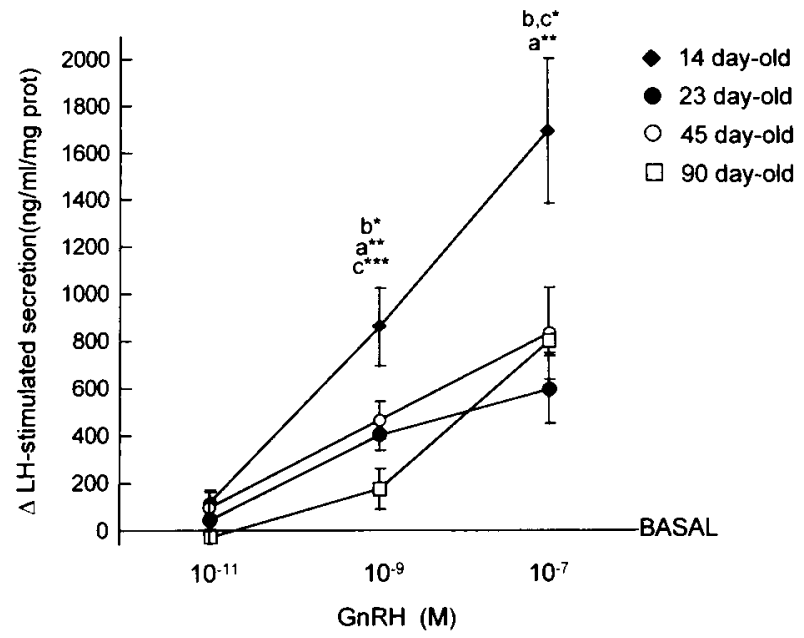

Figure 4 Increase in LH secretion after GnRH stimulation of 14-, 23-, 45- and 90-day-old male rat pituitaries. Data were obtained from the experiments shown in Figs $1-3$ and 5, and were the cumulative amount of the increment in $\mathrm{LH}$ secretion at different GnRH concentrations obtained in each 20 min period over its basal secretion. Values are means \pm S.E.M. Comparisons between groups: (a) 14 days vs 23 days, (b) 14 days vs 45 days, (c) 14 days vs 90 days; ${ }^{*} P<0 \cdot 05,{ }^{* * P} P<0 \cdot 01,{ }^{* * *} P<0 \cdot 001$; two-way ANOVA-Tukey-Kramer test.

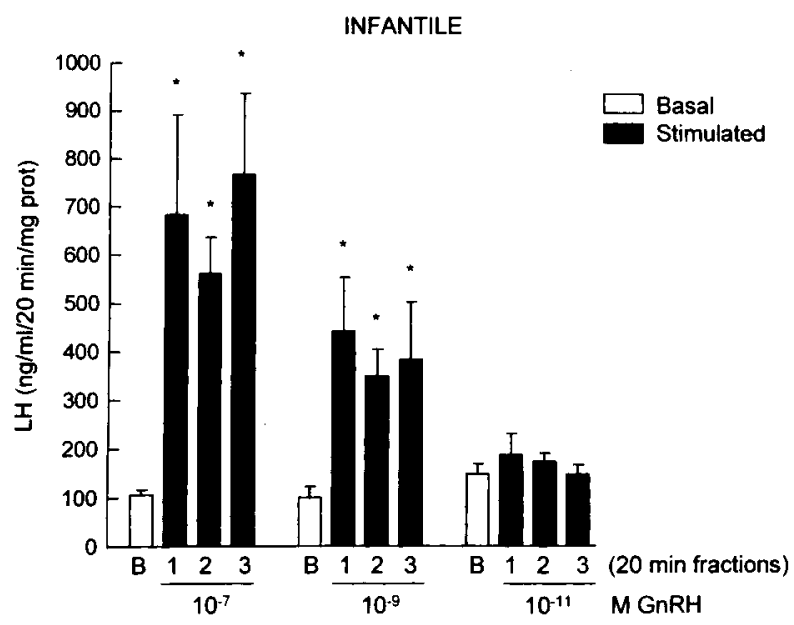

Figure $5 \mathrm{LH}$ secretion of pituitaries from 14-day-old male rats stimulated with different GnRH concentrations. Values are means \pm S.E.M., $n=6$. Comparisons with respect to basal secretion of each gland; ${ }^{*} P<0 \cdot 05$, Wilcoxon nonparametric test.

showed significant differences, similar to that observed in the whole gland at those ages (Fig. 6). The increase over basal $\mathrm{LH}$ secretion induced by $10^{-7} \mathrm{M} \mathrm{GnRH}$ at 24 and $48 \mathrm{~h}$ of culture of infantile cells was $515 \pm 69 \%$ and $565 \pm 79 \%$ respectively. Under the same experimental conditions the adult cells showed an increase in the LH secretion of $74 \pm 15 \%$ at $24 \mathrm{~h}$ of culture, and $135 \pm 21 \%$ at $48 \mathrm{~h}$ of culture. The difference between infantile and adult cells in the GnRH-induced release of $\mathrm{LH}$ was highly 
Table 1 In vitro basal LH secretion ( $\mathrm{ng} / \mathrm{ml}$ per $\mathrm{mg}$ protein \pm S.E.M.) by pituitaries from male rats at different postnatal ages. The $\mathrm{LH}$ concentration corresponds to the spontaneous LH secretion during a 20 min period

Rat ages (days)

\begin{tabular}{|c|c|c|c|}
\hline 14 & 23 & 45 & 90 \\
\hline $134 \pm 20^{* * a, * * * b}$ & $345 \pm 44$ & $409 \pm 55$ & $214 \pm 25^{* * \mathrm{c}}$ \\
\hline
\end{tabular}

Statistical differences were analyzed by ANOVA followed by Tukey-Kramer test. ${ }^{* * *} P<0 \cdot 001,{ }^{* *} P<0 \cdot 01 ; n=17$. ${ }^{\mathrm{a}} 14$ days vs 23 days, ${ }^{\mathrm{b}} 14$ days vs 45 days, ${ }^{c} 90$ days vs 45 days.

significant $(P<0 \cdot 001$, unpaired Student's $t$-test $)$. From these data it is clear that in the two culture periods studied, the response to $\mathrm{GnRH}$ is significantly larger in cells from 14-day-old rats than in those from 90-day-old rats.

\section{Immunocytochemistry for $\mathrm{LH}$}

The immunolocalization of LH-positive cells in the anterior pituitary of infantile rats showed that these cells are localized mainly at the periphery of the gland and beneath the intermediate lobe, with a highly immunofluorescent band of cells at the anterior face of the gland (Fig. 7A). In the adult gland the LH-positive cells were observed at the periphery of the gland and concentrated in the anterior-ventral area (Fig. 7B). However, when examined individually (Fig. 8), LH-positive cells in pituitaries from 14- and 90-day-old rats showed differences in size, with a higher proportion of smaller cells in the infantile pituitary (Fig. 8A) than in the adult (Fig. 8C). When the diameters of LH-positive cells from infantile

$24 \mathrm{~h}$

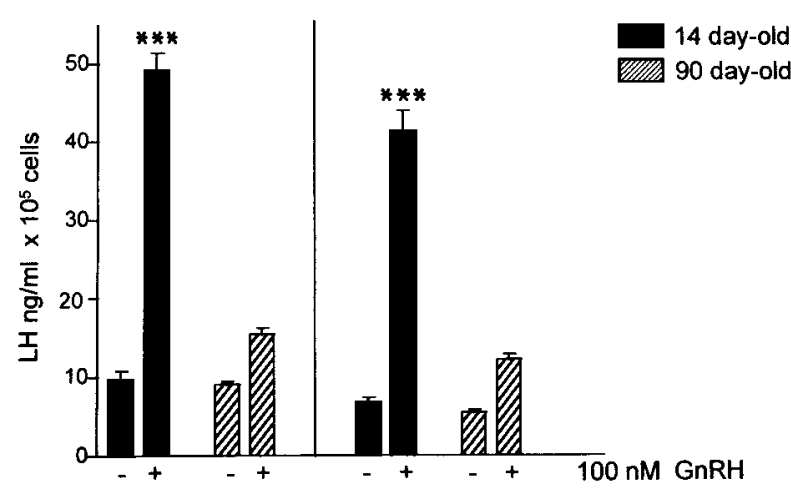

Figure 6 Basal and $\mathrm{GnRH}$-stimulated $\mathrm{LH}$ secretion of infantile or adult pituitary cells in 24 and $48 \mathrm{~h}$ of culture. The cells were washed and incubated for $60 \mathrm{~min}$ to achieve basal $\mathrm{LH}$ secretion and at the end of this period the medium was collected and another $60 \mathrm{~min}$ period was performed with $10^{-7} \mathrm{M} \mathrm{GnRH}$.

Statistical differences between infantile and adult secretion at each culture period were analyzed by ANOVA followed by Tukey-Kramer test; ${ }^{* * * P<0 \cdot 001 .}$ glands were measured an uneven distribution was observed. Cells with an average $9 \mu \mathrm{m}$ diameter were seen at the periphery of the lateral faces of the gland, whereas in the anterior area most of the cells averaged $11 \mu \mathrm{m}$. The median cell size obtained over the entire gland of adult rats was $11.5 \mu \mathrm{m}$. The diameter of the LH-positive cells in the periphery of the lobes of the infantile pituitary was statistically different from that of the cells from the center of the gland, and from adult cells (Table 2). We also found $10 \%$ more LH-positive cells in the infantile glands than in the adult pituitaries.

\section{Discussion}

This study shows that the infantile LH gonadotropes from male rats are overall more responsive to GnRH stimulation than in later periods of postnatal development. The male infantile $\mathrm{LH}$ cells secrete $\mathrm{LH}$ in amounts similar to those of juvenile, pubertal and adult pituitaries, but with a GnRH stimulus 100 times smaller. By employing a similar incubation system, an earlier study reported comparable results (Spona \& Luger 1973), although the differences between infantile glands and those obtained at other ages were more modest, even when the GnRH dose was considerably higher. On the contrary, Dullaart (1977) obtained a pattern of $\mathrm{LH}$ release characterized by a steady increase with age. Differences in methodologies could underlie the discrepancy between Dullaart's data and our own results. Dullaart incubated six hemipituitaries in each vial, for basal and stimulated release, and the amount of LH obtained was the sum of the LH secreted by the six glands during a $2 \mathrm{~h}$ incubation period. In our study, we used a pituitary in each vial, and the basal and the stimulated LH secretion were obtained from the same gland, and we obtained the $\mathrm{LH}$ secreted into the incubation medium during a $20 \mathrm{~min}$ period. Furthermore, our experience was that some pituitaries could not stabilize, showing a spontaneous LH secretion considerably higher, masking the increase in LH release from the responsive pituitaries induced by GnRH. The elevated stimulated LH secretion observed in the present study by infantile male pituitaries is similar to that observed in the infantile female rat in vivo in response to the administration of a bolus of GnRH (Ojeda et al. 1977) and also in vitro (Spona \& Luger 1973, Dullaart 1977). The enhanced GnRH response observed in female rats is in part due to an increase in the population of gonadotrope cells (Denef et al. 1978). Furthermore, according to Dalkin et al. (1981) female rats exhibit a peak in GnRH receptor density around the 14th day that could explain the higher LH serum concentration and the hypersensitivity to $\mathrm{GnRH}$ observed in the infantile period. However, male rats exhibit a different pattern in pituitary GnRH receptors during postnatal development, with $\mathrm{GnRH}$ receptors increasing in number steadily at 5 days to reach a maximum level at 30 days of age (Dalkin et al. 1981). However, our results showed that the anterior 


\section{A}
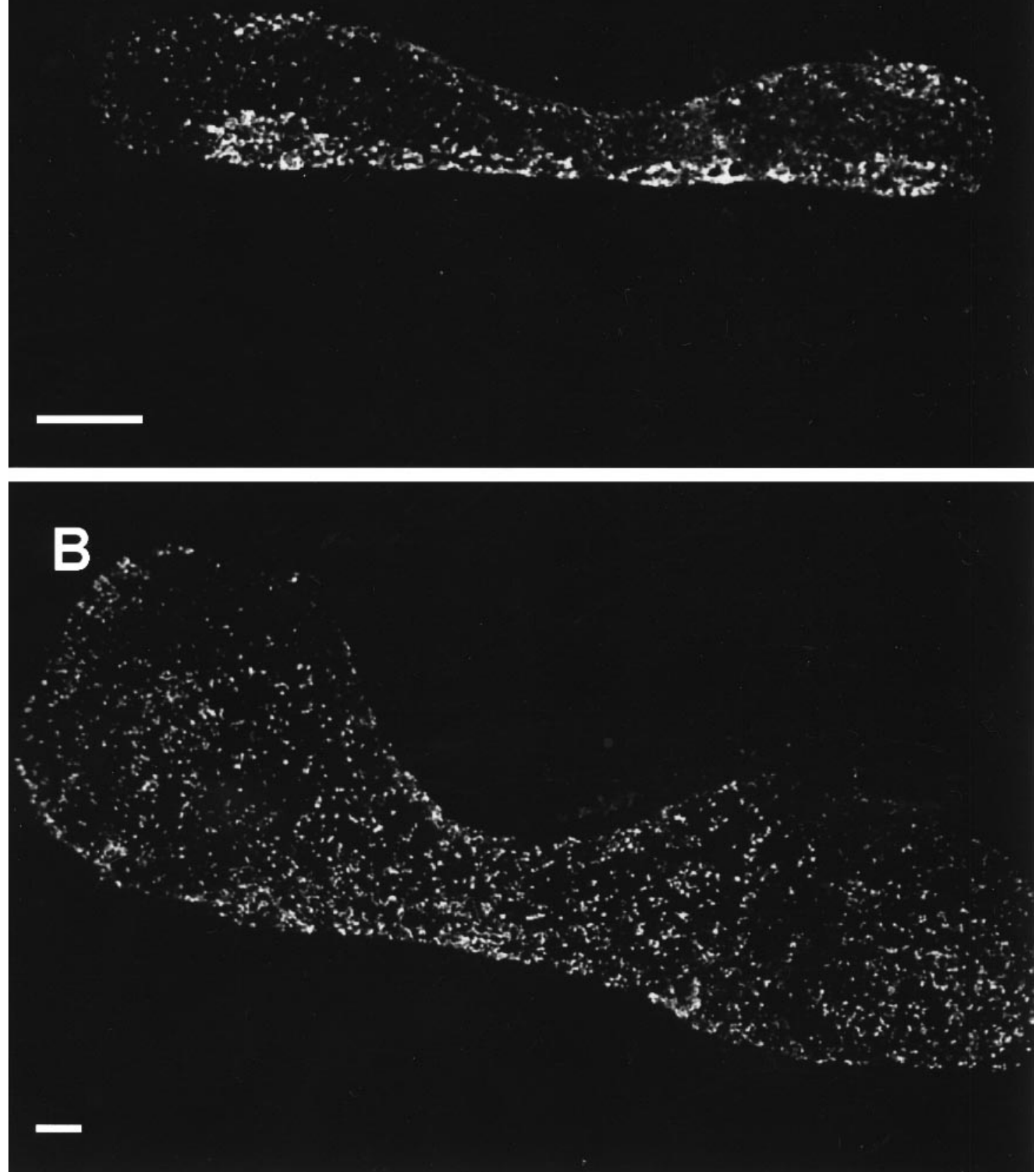

Figure 7 Immunolocalization of LH-positive cells in 14-day-old (A) and 90-day-old (B) rat pituitaries. The cells were labeled with an antibody against $\mathrm{LH} \beta$ and developed with $\mathrm{ABC}$ alkaline phosphatase and Fast Red as substrate. The posterior lobe was the negative control. The immunostaining of the 14-day-old gland was localized mainly at the anterior face and at the periphery of the gland, and the 90-day-old gland shows numerous staining at the anterior ventral area. The tissue sections shown in the photomicrographs correspond to the middle of the glands. Bar $=250 \mu \mathrm{m}$. 

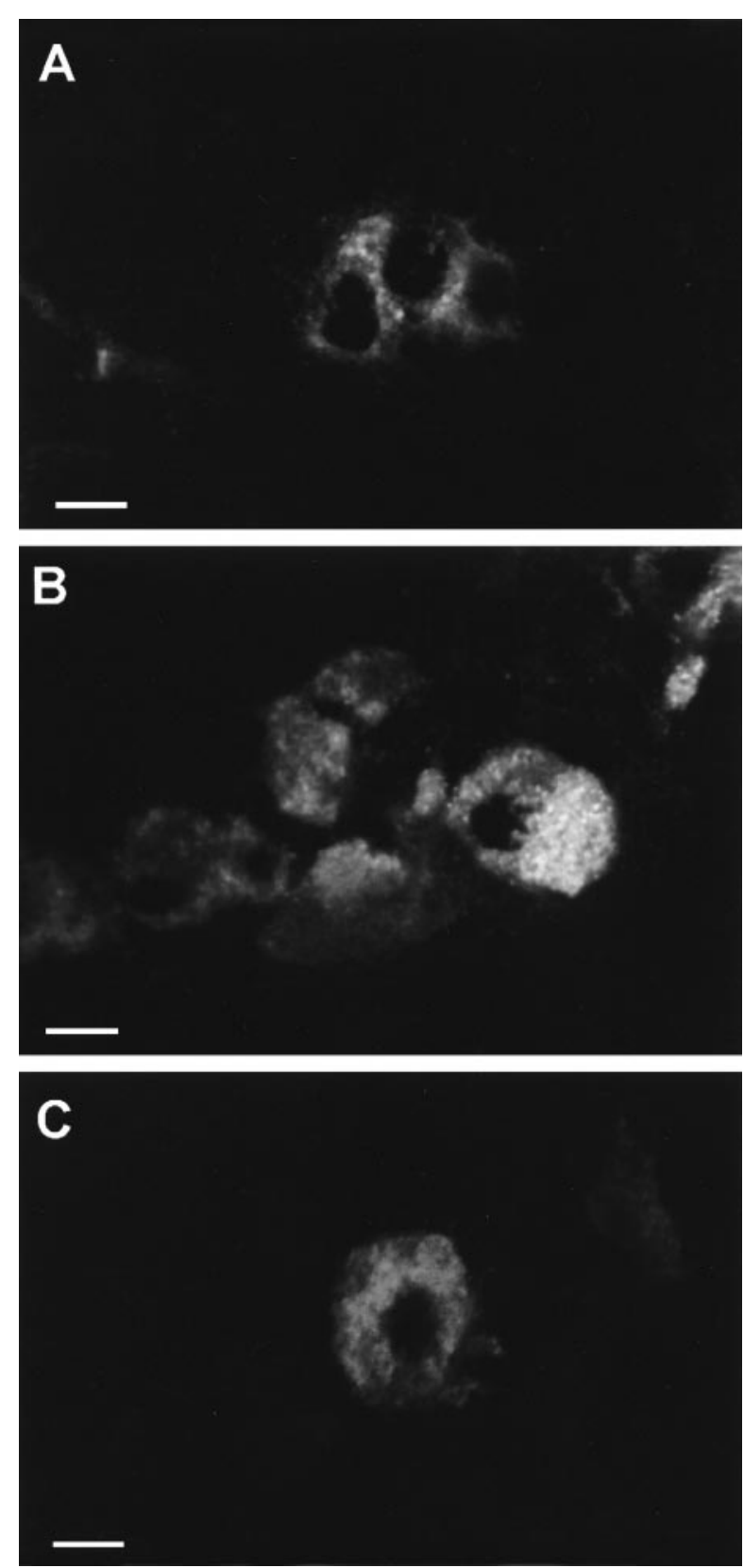

Figure 8 Morphological characteristics of LH-positive cells from 14- and 90-day-old anterior rat pituitaries. Panels A and B show the different types of LH-positive cells found in 14-day-old glands. Panel C shows a typical adult LH-positive cell. The cells were labeled with an antibody against $\mathrm{LH} \beta$ and stained with $\mathrm{ABC}$ alkaline phosphatase and Fast Red as substrate. Bar $=5 \mu \mathrm{m}$.

pituitaries from juvenile rats did not exhibit a stimulated LH secretion greater than that found during the infantile period, suggesting that the gonadotropin secretion is negatively modulated at the juvenile period. The lower density of $\mathrm{GnRH}$ receptors observed in the infantile male pituitary
Table 2 LH-positive cells diameters from 14- and 90-day-old male rat pituitaries. The $\mathrm{LH}$-positive cells are different in size according to their location in the infantile gland ( 14 days old). Adult LH-positive cells do not exhibit regional size differences

\begin{tabular}{|c|c|c|c|c|}
\hline \multirow{2}{*}{\multicolumn{2}{|c|}{$\begin{array}{l}\text { Localization } \\
\text { in the gland }\end{array}$}} & \multicolumn{3}{|c|}{ Diameter $(\mu \mathrm{m})$} \\
\hline & & Median & Mean & S.E.M. \\
\hline \multicolumn{5}{|c|}{$\begin{array}{l}\text { Rat age } \\
\text { (days) }\end{array}$} \\
\hline \multirow[t]{2}{*}{14} & Lobules & $9 \cdot 0 * * *$ & $9 \cdot 2$ & $0 \cdot 1$ \\
\hline & Center & $11 \cdot 1$ & $11 \cdot 4$ & $0 \cdot 2$ \\
\hline 90 & Whole & $11 \cdot 5$ & $11 \cdot 60$ & $0 \cdot 1$ \\
\hline
\end{tabular}

Statistical differences were observed between 14-day-old pituitary lobules with respect to 14-day-old center and 90-day-old pituitary (Kruskal-Wallis test followed by Dunn's test). ${ }^{* * *} P<0 \cdot 001 ; n=300$ cells.

compared with female pituitaries (Dalkin et al. 1981) could explain the moderate serum LH concentration in infantile males compared with that observed in infantile female rats (Ojeda \& Ramirez 1972, Döhler \& Wuttke 1975, Chiappa \& Fink 1977). However, we believe that the higher capacity of the infantile pituitary to secrete LH under GnRH stimulation could be a functional characteristic and linked to the morphology of the LH-positive cells present in the pituitary at this stage of development.

It was not surprising that the basal secretion of $\mathrm{LH}$ was different among the ages studied. In the earlier work of Spona \& Luger (1973), a higher basal LH secretion by pubertal pituitaries was obtained, similar to that reported herein. However, they observed a low basal secretion by juvenile pituitaries, which is at odds with our results. We believe that hypothalamic GnRH could be implicated in the higher basal LH secretion observed in juvenile and pubertal pituitaries, since at these development periods the hypothalamus shows bursts of GnRH secretion that could stimulate LH synthesis and lead to elevated secretion of LH (Ojeda \& Urbanski 1988).

Our data show a clear difference between infantile and adult stimulated LH secretion, this being significantly larger in the infantile pituitaries, possibly suggesting a hypersensibility to $\mathrm{GnRH}$ at this developmental stage. Likewise, a different time course of GnRH-stimulated LH secretion was observed. With infantile pituitaries, the highest secretion of $\mathrm{LH}$ in response to $\mathrm{GnRH}$ was obtained during the first period of incubation, in contrast to adult pituitary where a step-wise increase in LH was observed during the three incubation periods. Taking into account that the location of most of the LH-positive cells is near the periphery and at the anterior-ventral area (Nakane 1968, 1970), where the glands were cut into two parts, and a delay of only $2 \cdot 5-5 \mathrm{~min}$ in the diffusion rates between adult and infantile glands, it is unlikely that a diffusion barrier could be responsible for the LH secretion differences observed. In accord with Denef \& Andries (1983) the results reported herein for primary cell cultures 
from infantile and adult pituitaries clearly show greater GnRH-induced LH secretion in the infantile cells. This difference was more evident at 24 than $48 \mathrm{~h}$ of culture because of an increase in the secretory response by the adult pituitary cells at $48 \mathrm{~h}$ of culture. Loughlin et al. (1984) observed that at $24 \mathrm{~h}$ postdispersion, the LH secretion reflects more accurately the hormonal environment and pituitary LH content found at the time that the animals were killed, but $24 \mathrm{~h}$ later the hormonal concentration of the culture medium seems to be the main factor influencing LH secretion. The increase in the stimulated LH secretion observed in adult pituitary cells at $48 \mathrm{~h}$ of culture could therefore reflect the activity of hormone steroids present in the fetal calf serum used in the culture medium.

Moreover, the infantile and adult pituitaries exhibit different proportions of LH-positive cells. LH-positive cells are more abundant $(+10 \%)$ in the pituitaries from 14-day-old rats. This result agrees with those of Denef et al. (1978) and Childs et al. (1981). Furthermore, a significant proportion of the infantile LH-positive cells are angular shaped, with long processes facing the sinusoids, whereas most adult LH-positive cells are ovoid shaped (Childs et al. 1981, Inoue \& Hagino 1984). However, according to Inoue \& Hagino (1984) the infantile folliclestimulating hormone (FSH)-positive cells are similar in shape to adult gonadotrope cells. In the present study we observed a regional distribution of the small LH-positive cells, with a great proportion of them being localized at the periphery of the lobules. However, according to Nakane (1970) adult pituitaries also show regional differences in the localization of mono-hormonal gonadotrope cells. $\mathrm{He}$ observed that in general the gonadotropic cells situated at the periphery of the gland contained both FSH and LH whereas those at the center tended to contain only one of these hormones. Data from our group have shown that infantile pituitary cells, cultured in defined medium containing fibroblast growth factor, can maintain their level of GnRH-induced LH secretion, whereas in adult male pituitary cells this growth factor cannot induce the same response (Cruz-Soto et al. 1996). The morphological and functional data obtained in gonadotrope cells from infantile male rats support the hypothesis that two different populations of LH-secreting cells are present in the pituitary at this period. These different populations could result from dissimilar stages of development of the same population, or arise from different cell precursors.

A number of previous works have shown the importance of serum LH concentrations for early postnatal development in the male rat (Chemes et al. 1979, Molenaar et al. 1986, Teerds et al. 1989). According to Teerds et al. (1989) the rate of development of the new Leydig cells during the postnatal period strongly depends on LH levels. Furthermore, the participation of LH has also been involved in the regulation of Sertoli cell differentiation (Chemes et al. 1979). Thus, the larger GnRH- stimulated LH secretion observed in infantile rat pituitaries compared with that in the adult could be important to testis development.

\section{Acknowledgements}

The authors would like to thank Dr A Arias-Montaño for his critical review of the manuscript, and also are grateful to Mrs Luz Ma Buendia for her secretarial assistance, and to biologist Carmen Solano, Mr Armando Vargas and $\mathrm{Mr}$ Jesús Velázquez for technical assistance. This work was supported by a grant from the National Council of Science and Technology of Mexico (1318P-N9507).

\section{References}

Bradford MM 1976 A rapid and sensitive method for the quantitation of microgram quantities of protein utilizing the principle of proteindye binding. Annals of Biochemistry 72 248-254.

Chemes HE, Dym M \& Raj HGM 1979 Hormonal regulation of Sertoli cell differentiation. Biology of Reproduction 21 251-262.

Chiappa SA \& Fink G 1977 Releasing factor and hormonal changes in the hypothalamic-pituitary-gonadotrophin and -adrenocorticotrophin systems before and after birth and puberty in male, female and androgenized female rats. Journal of Endocrinology 72 211-224.

Childs G (Moriarty), Ellison D, Foster L \& Ramaley JA 1981 Postnatal maturation of gonadotropes in the male rat pituitary. Endocrinology 109 1683-1692.

Cruz-Soto ME, Toral C, Romano M \& Mendoza ME 1996 Female 14-day-old rat anterior pituitary cells require fibroblast growth factor and a collagen-fibronectin matrix to develop in a defined medium. Boletin de Estudios Médicos y Biológicos, México 44 86-89.

Dalkin AC, Bourne GA, Pieper DR, Regiani S \& Marshall JC 1981 Pituitary and gonadal gonadotropin-releasing hormone receptors during sexual maturation in the rat. Endocrinology 108 1658-1664.

Denef C \& Andries M 1983 Evidence for paracrine interaction between gonadotrophs and lactotrophs in pituitary cell aggregates. Endocrinology 112 813-822.

Denef C, Huatekeete E, de Wolf A \& Vanderschueren B 1978 Pituitary basophils from immature male and female rats: distribution of gonadotrophs and thyrotrophs as studied by unit gravity sedimentation. Endocrinology 103 724-735.

Döhler KD \& Wuttke W 1975 Changes with age in levels of serum gonadotropins, prolactin and gonadal steroids in prepubertal male and female rats. Endocrinology 97 898-907.

Dullaart J 1977 Immature rat pituitary glands in vitro: age- and sex-related changes in luteinizing hormone-stimulated gonadotrophin release. Journal of Endocrinology 73 309-319.

Goldman BD, Grazia YR, Kamberi IA \& Porter JC 1971 Serum gonadotropin concentrations in intact and castrated neonatal rats. Endocrinology 88 771-778.

Grady RR 1986 Effect of neonatal treatment with the sex-opposite steroid on gonadotropin responsiveness in rats. Neuroendocrinology 43 322-330.

Hernández ME, Reyes JL, Gómez-Lojero C, Sayavedra MS \& Meléndez E 1993 Inhibition of the renal uptake of $p$-aminohippurate and tetraethylammonium by the antioxidant ethoxyquin in the rat. Food and Chemical Toxicology 31 363-367.

Inoue K \& Hagino N 1984 Comparative immunocytochemical demonstration of ACTH-, LH- and FSH-containing cells in the pituitary of neonatal, immature and adult rats. Cell and Tissue Research 235 71-75.

Lalau J-D, Aubert ML, Carmignac DF, Grégoire I \& Dupouy J-P 1990 Reduction in testicular function in rats. I. Reduction by a 
specific gonadotropin-releasing hormone antagonist in fetal rats. Neuroendocrinology 51 284-288.

Loughlin JS, Naddaff PG \& Badger TM 1984 LH responses to LHRH in perifused pituitary cell culture: sex differences in the rat. American Journal of Physiology 246 E145-E152.

Mendoza ME, Martín D, Candelaria PG \& Romano MC 1995 Evidence that secretory products of the reticulo-epithelial cells of the rat thymus modulate the secretion of gonadotrophins by rat pituitary cells in culture. Journal of Reproductive Immunology 28 203-215.

Molenaar R, de Rooij DG, Rommerts FFG \& van der Molen HJ 1986 Repopulation of Leydig cells in mature rats after selective destruction of the existent Leydig cells with ethylene dimethane sulfonate is dependent on luteinizing hormone and not folliclestimulating hormone. Endocrinology 118 2546-2554.

Nakane PK 1968 Simultaneous localization of multiple tissue antigens using the peroxidase-labeled antibody method: a study on pituitary glands of the rat. Journal of Histochemistry and Cytochemistry 16 $557-560$.

Nakane PK 1970 Classifications of anterior pituitary cell types with immunoenzyme histochemistry. Journal of Histochemistry and Cytochemistry 18 9-20.

Naor Z \& Childs GV 1981 Gonadotropin releasing hormone binding and activation of enriched populations of gonadotropes. In Proceedings of the 63rd Annual Meeting of The Endocrine Society, Cincinnati, OH, USA, p 953 (Abstract).

Negro-Vilar A \& Valenca MM 1988 Male neuroendocrinology and endocrine evaluation of reproductive disorders. In Physiology and Toxicology of Male Reproduction, ch 5, pp 103-136. Eds JC Lamb \& MD Foster. New York: Academic Press Inc.
Ojeda SR \& Ramírez VD 1972 Plasma levels of LH and ESH in maturing rats: response to hemigonadectomy. Endocrinology 90 466-472.

Ojeda SR \& Urbanski HF 1988 Puberty in the rat. In The Physiology of Reproduction, ch 39, pp 1699-1737. Eds E Knobil \& J Neill. New York: Raven Press, Ltd.

Ojeda SR, Jameson HE \& McCann SM 1977 Developmental changes in pituitary responsiveness to luteinizing-releasing hormone $(\mathrm{LHRH})$ in the female rat: ovarian-adrenal influence during the infantile period. Endocrinology 100 440-451.

Ojeda SR, Andrews WW, Advis JP \& Smith-White S 1980 Recent advances in the endocrinology of puberty. Endocrine Reviews $\mathbf{1}$ 228-257.

Spona J \& Luger O 1973 In vitro responsiveness of male rat pituitaries of different ages to LH-releasing hormone (LH-RH). FEBS Letters 32 49-51.

Swerdloff RF, Walsh PC, Jacobs HS \& Odell WD 1971 Serum LH and FSH during sexual maturation in male rat: effect of castration and cryptorchidism. Endocrinology 88 120-128.

Teerds KJ, de Rooij DG, Rommerts FFG, van den Hurk R \& Wensing CJG 1989 Proliferation and differentiation of possible Leydig cell precursors after destruction of the existing Leydig cells with ethane dimethyl sulphonate: the role of LH/human chorionic gonadotrophin. Journal of Endocrinology 122 689-696.

Received 4 June 1998

Revised manuscript received 28 September 1998 Accepted 7 October 1998 